\title{
Deformation at a strike-slip, stepover zone along the southeastern margin of the Dead Sea pullapart basin, Jordan
}

\author{
M. Atallah ${ }^{1}$, T. M. Niemi ${ }^{2}$, and H. Mustafa ${ }^{1}$ \\ ${ }^{1}$ Department of Earth and Environmental Sciences, Yarmouk University, Irbid, Jordan \\ ${ }^{2}$ Department of Geosciences, University of Missouri-Kansas City, Missouri, USA
}

Received: 20 November 2000 - Revised: 11 February 2002 - Accepted: 27 March 2002

\begin{abstract}
Detailed stratigraphic and structural study of the southeast Dead Sea basin along the Dead Sea Transform in Jordan was carried out in order to determine the deformation history and processes of pullapart basin formation. Fieldwork focused on mapping and collecting structural orientation data in the area of the intersection of the NE-trending, strike-slip Wadi Araba fault (WAF) and the NW-trending, dip-slip Khunayzira fault. The recent movement on the WAF shows spectacular polished fault planes, slickensides, and Riedel and conjugate Riedel shears. During the Late Quaternary the position of the WAF shifted west toward the basin. This is evident from a series of pressure ridges and exposed positive flower structures that do not deform the lacustrine deposits of the Lisan formation (63-15 ka). The Khunayzira fault makes a prominent, curvilinear $50 \mathrm{~m}$-high scarp that trends SE-NW. In the study area, the scarp is highly eroded and sinuous. Slip on the Khunayzira fault branches onto four fault traces near the junction with the WAF. No cross-cutting relationship is observed between the Khunayzira and WAF. These data contradict the idea that strike-slip motion on the WAF terminates and is transferred to dip slip along the Khunayzira fault. Our data agree with the more complex model of the Dead Sea pull-apart basin, that explain the activity of the transverse faults as younger than the formation of the basin. Paleostress calculations based on fault-slip data of the WAF and the faults of the Upper Cretaceous rock show two stress fields. The first is characterized by WNW compression and NNE tension, which represent the Syrian Arc stress field. The second is characterized by NNW compression and ENE tension, which represents the Dead Sea stress field.
\end{abstract}

\section{Introduction}

The Dead Sea, $>400 \mathrm{~m}$ below sea level, is an actively subsiding basin formed along the Dead Sea transform (DST) plate boundary which separates the Sinai-Palestine subplate on the

Correspondence to: M. Atallah (matallah@yu.edu.jo) west from the Arabian plate on the east (Fig. 1). A total sinistral displacement of $107 \mathrm{~km}$ along the transform has occurred since the inception of the shear zone in the Miocene (e.g. Quennell, 1959; Freund et al., 1970). The DST can be divided into five major fault provinces. From south to north, these are: the Gulf of Aqaba, Wadi Araba, Jordan Valley, Yammouneh, and El Ghab (Orontes). These segments include or are separated by large morphotectonic sedimentary basins that have formed between en echelon, left-stepping segments of the DST. Present-day microseismicity indicates a clustering of seismic activity in these major basins (van Eck and Hofstetter, 1990). The entire length of the southern transform exhibits rift morphology due to divergent plate motion (leaky transform of Garfunkel, 1981).

The Dead Sea sedimentary basin is filled with nearly $10 \mathrm{~km}$ of Miocene to Holocene sediments (e.g. Garfunkel, 1997; Gardosh et al., 1997). Due to rapid subsidence of the Dead Sea basin and fluctuations of the water bodies that have filled the depression since the Pliocene, extensive outcrops of basin margin deposits are impressively exposed in wadi incisions on both sides of the Dead Sea. These sediments have recorded the ongoing deformation processes produced by transtension along the Dead Sea transform system.

Although the Dead Sea is cited as a classic example of a pull-apart basin (e.g. Wilcox et al., 1973), there remain many unresolved questions about its structural style and history, the complex relationship between active structures and reactivation of ancient structures, and the partitioning of strain. This study presents structural orientation data collected at the intersection of the strike-slip Wadi Araba (Arava) fault which bounds the southeast margin of the Dead Sea basin and the transverse, dip-slip Khunayzira (Amatzayahu) fault. The goal of this study is to resolve the local relative stress axes of lithologic units of various ages in order to understand the deformation history and process of strain transfer in an active, evolving pullapart basin. 


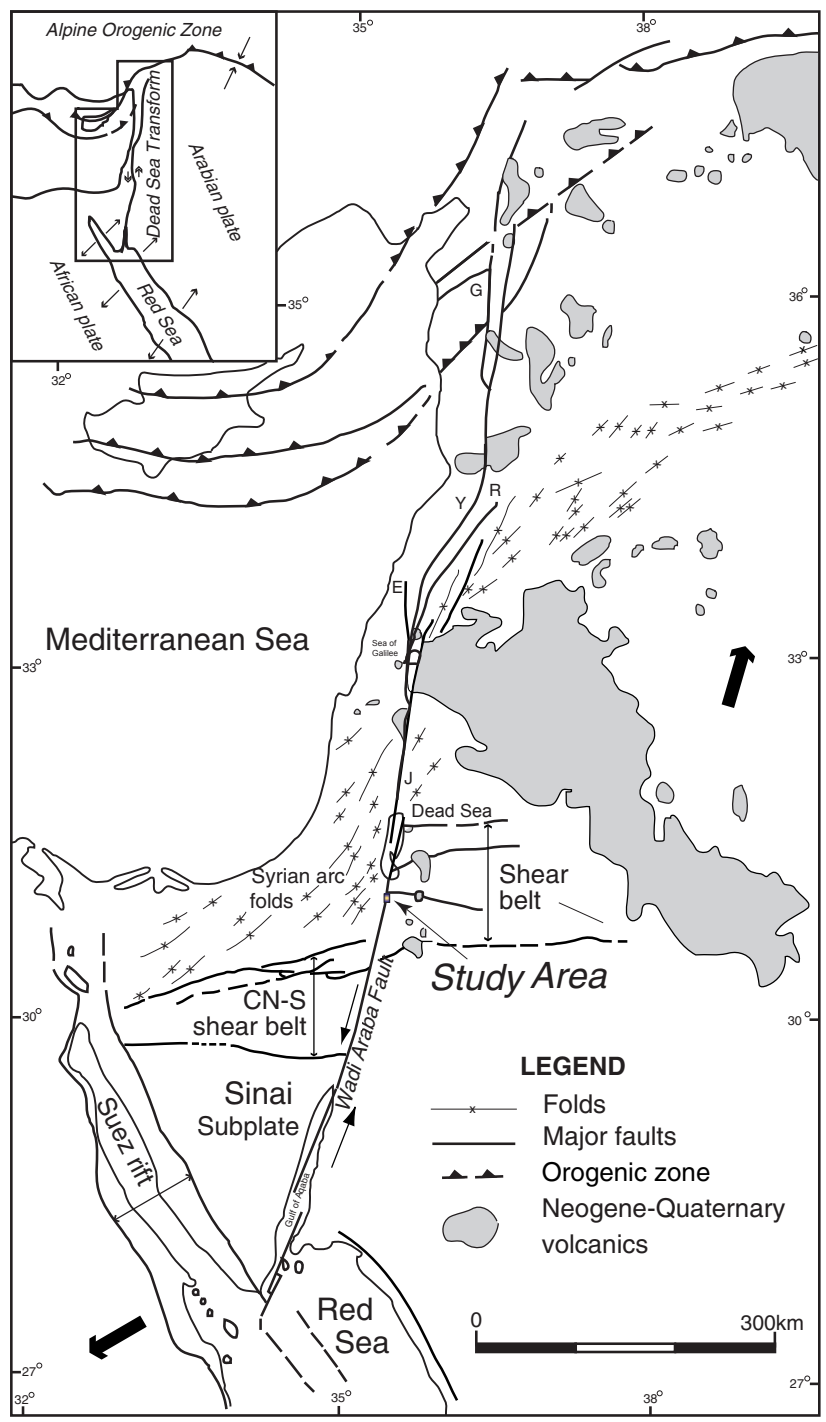

Fig. 1. The Dead Sea Transform (DST) is the plate boundary fault system that separates the Sinai and Arabian plates (after Garfunkel, 1981). G: Ghab fault, Y: Yammouneh fault, R: Rachaiya fault, E: Ed Damor fault, CN-S: Central Negev-Sinai shear belt.

\section{Tectonic setting}

The Dead Sea transform (DST) is a $1100 \mathrm{~km}$-long plate boundary that connects Red Sea spreading in the south with continental collision in the Taurus-Zagros mountain belt and eastward escape of the Anatolian plate in the north (Fig. 1). The Red Sea spreading rate at the latitude of the NubianSinai-Arabia triple junction is estimated as $9 \mathrm{~mm} / \mathrm{yr}$ directed along N25-30 ${ }^{\circ} \mathrm{E}$ (Courtillot et al., 1987). Estimated geologic slip rate of $6-10 \mathrm{~mm} / \mathrm{yr}$ for the DST is based on a cumulative offset of $107 \mathrm{~km}$ of Miocene and older rocks (e.g. Zak and Freund, 1966; Freund et al., 1970). The commencement of displacement along the DST, based on equal displacement of Precambrian contacts and $20 \mathrm{Ma}$ basaltic dikes, (Bartov et al., 1980; Eyal et al., 1981) did not occur before the intrusion of the dikes. Hence, the mean rate of slip along the southern segment of the DST is in the order of $5.5 \mathrm{~mm} / \mathrm{yr}$. Based on an airphoto reconnaissance of the DST and earthquake catalogue information, Garfunkel et al. (1981) suggested that present-day slip rate has been slower $(1.5-3.5 \mathrm{~mm} / \mathrm{yr})$ when compared to Plio-Pleistocene rates. A recent study of offset alluvial fans near Ar-Risha (Ginat et al., 1998) estimate long term slip rates between $3.0-7.5 \mathrm{~mm} / \mathrm{yr}$ since the late Pliocene-early Pleistocene. However, at that location, only relative age control was used. Recent work on offset alluvial fan surfaces and drainages along the northern Wadi Araba fault indicates a minimum $4.7 \pm 1.3 \mathrm{~mm} / \mathrm{yr}$ slip rate since $15 \mathrm{ka}$ (Zhang, 1998; Niemi et al., 2001). Klinger et al. (2000) reports a late Quaternary slip rate of the northern Wadi Araba fault of 3-7 mm/yr based on cosmogenically dated displaced surfaces of the Wadi Dahal allluvial fan.

Chu and Gordon (1998) considered the azimuth of the DST unreliable for plate motion reconstruction between Arabia and Nubia (AR:NU). The strike of the DST and the transform-normal extension are two components of the AR:NU slip vector. In the region south of the Dead Sea, three distinct sets of fault trends have been mapped (e.g. Gulf of Aqaba, Ben-Avraham, 1985; Dead Sea, ten-Brink and BenAvraham, 1989). The major, strike-slip faults trends N15$20^{\circ} \mathrm{E}$, the basin-bounding normal faults are subparallel to the strike-slip faults, and several transverse dip-slip or obliqueslip faults trend approximately N50-60 W. At the Dead Sea, the transform strike bends $10^{\circ}$ to the west and the character of the DST continues to change northward from strike slip to oblique slip and dip slip.

The pull-apart basin model describes the formation of sedimentary basins between en enchelon strike-slip faults by extension directed parallel to the strike of the transform (Wilcox et al., 1973; Crowell, 1974; Aydin and Nur, 1982). Katzman et al. (1994) and ten-Brink et al. (1996) using 3-D boundary element models of pure, strike-slip faults arranged in an en enchelon pattern show that fault normal extension and the formation of a full graben is a product of fault interaction in the overlap zone. Subsidence extends outside the overlap zone and is seen as asymmetrical (half graben) with uplift manifested at the fault tips. Oblique opening $(\sim 10 \%$ of strike-slip motion) produces similar features over a wider zone of subsidence.

Further complications in interpreting the DST crustal deformation may be due to stress field fluctuations. Eyal (1996) postulated that the present stress field fluctuates between the Syrian Arc fold belt (WNW shortening, NNE extension) and a Dead Sea transform (NNW shortening, ENE extension) depending on the seismic cycle of large DST earthquakes. AlDiabat (1999) suggested a similar bimodal stress field system based on fault slip data collected east of the DST. These data oppose the prevailing clay model experiments by Wilcox et al. (1973) that suggest en enchelon folds develop early in the shear process. Other models suggest the Syria Arc fold belt formed prior to the inception of the DST (Eyal and Reches, 1983). It is evident from these examples that additional data are need in order to understand the neotectonic behavior of faults within the Dead Sea basin.

In this study we present structural orientation data from 


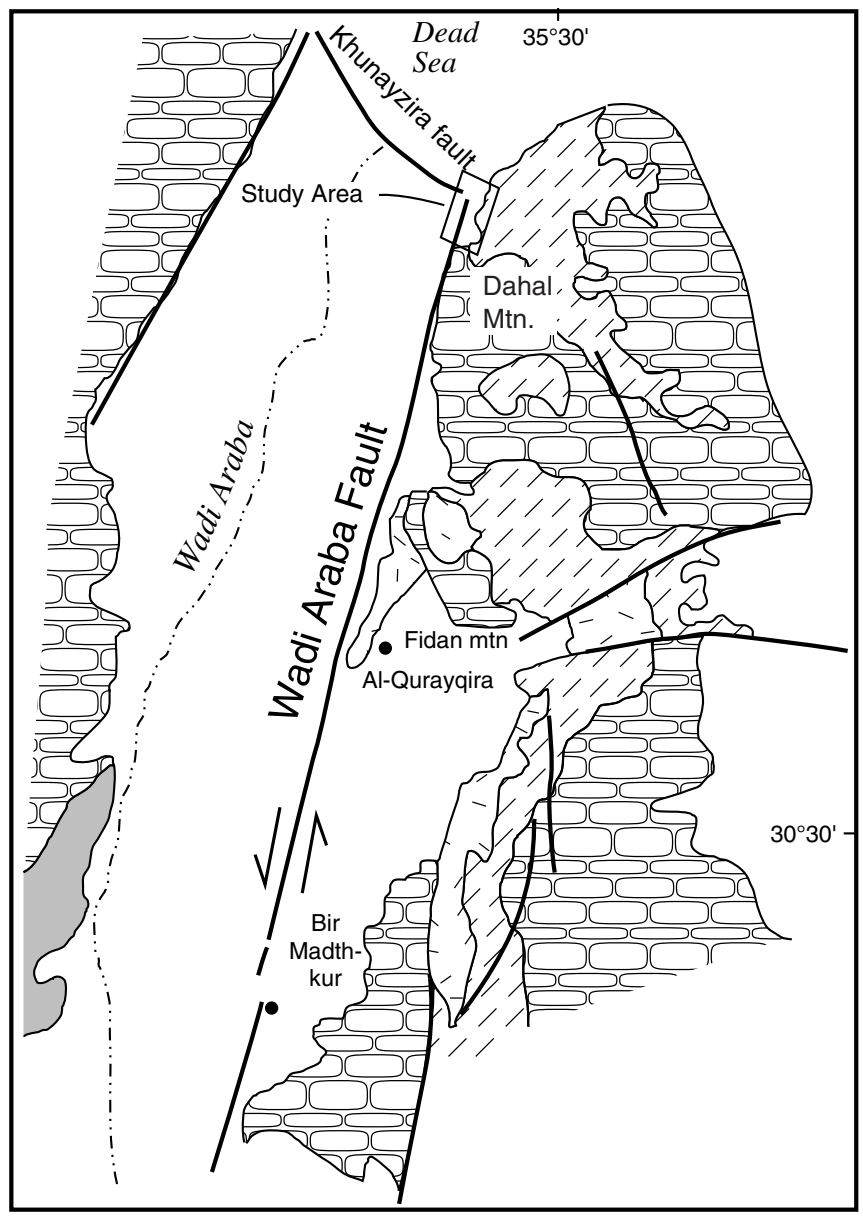

\section{KEY}

\begin{tabular}{|c|c|}
\hline & $\begin{array}{l}\text { Quaternary } \\
\text { Alluvium, lacustrine, aeolian, } \\
\text { mudflat (sabkha) deposits }\end{array}$ \\
\hline & $\begin{array}{l}\text { Tertiary } \\
\text { Eocene-Paleocene limestone } \\
\text { Oligocene-Pliocene? oolitic limestone, } \\
\text { nonmarine conglomerate }\end{array}$ \\
\hline & $\begin{array}{l}\text { Cretaceous } \\
\text { Lower Cretaceous sandstone } \\
\text { Upper Cretaceous limestone, marl, } \\
\text { chert, shale, phosphorite }\end{array}$ \\
\hline 11 & $\begin{array}{l}\text { Paleozoic } \\
\text { Cambrian-Silurian limestone, } \\
\text { dolomite, shale, and sandstone }\end{array}$ \\
\hline & $\begin{array}{l}\text { Late Precambrian } \\
\text { Granite, monzogranite } \\
\text { granodiorite, quartz diorite; } \\
\text { minor metamorphic roof } \\
\text { pendants }\end{array}$ \\
\hline
\end{tabular}

Fig. 2. Generalized geologic map of Wadi Araba showing juxtaposition of different bedrock lithologies across the valley. The Wadi Araba fault is an active, strike-slip fault of the DST. The study area is located at the intersection of the Wadi Araba fault and the Khunayzira normal fault. Map modified after Bender, 1975.

clastic and chemical sediments along the southeast margin of the Dead Sea pullapart basin at a critical stepover fault location. We use the structural orientation data in units of various ages to test whether data of the deformation history shows two overlapping coeval stress fields.

\section{Study area}

The study area is located southeast of the Dead Sea at the intersection of the Khunayzira (Amatzayahu) dip-slip fault and the Wadi Araba strike-slip fault in Jordan (Fig. 2). This location was selected because of its potential to yield information on the geometric relationships at a step-over zone in a pullapart basin. Stream incisions and artificial exposures make the stratigraphic units and structures accessible for structural analyses. Two major streams cross the study area, the Wadi Khunayzira and Wadi An Nakhbar (Fig. 3). These streams have deep canyons along which the rocks and the faults are well exposed.

Previous studies of the southeastern area of the Dead Sea are included in regional studies of the DST rift valley. Gar- funkel et al. (1981) and Galli (1999) mapped the active late Quaternary faults along the Dead Sea-Jordan transform from air photos. The Wadi Araba fault (WAF) and regional geology in the study area was also mapped (Tarawneh, 1992) as part of the Jordanian National Resource Authority 1:50 000 scale geologic mapping program (Fig. 2).

The Wadi Araba valley floor is an area of badland topography. Most of this area is covered by the easily eroded, flatlying lacustrine sediments (including marl and clastic sections) of the Upper Pleistocene Lisan Formation. The study area is located at the margin of the Lake Lisan which covered a large area of the Dead Sea rift during the Late Quaternary, ca. 63-15 ka (Kaufman et al., 1992). Base level lowering of the Wadi Araba drainage has been controlled by changes in the lake level of the Dead Sea and the Late Pleistocene precursor, Lake Lisan. The Dahal mountains are the bare bedrock region east of Wadi Araba fault. High relief is marked by elevation that ranges from $170 \mathrm{~m}$ below the mean sea level (MSL) to $408 \mathrm{~m}$ above MSL. The bedrock has been strongly dissected by headward erosion of the major drainages. 


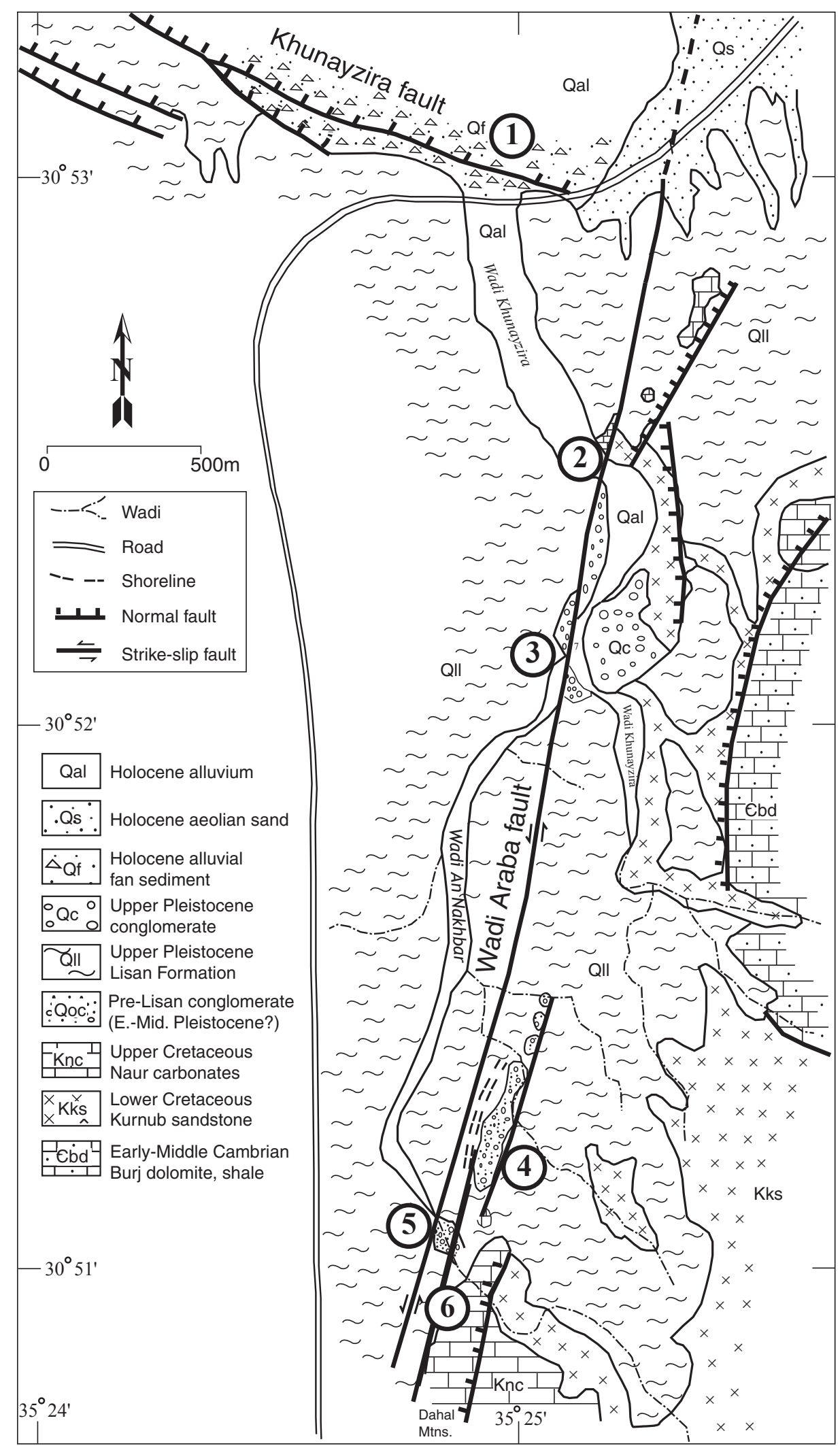

Fig. 3. Geologic map of the study area constructed from interpretation of 1:10000 scale black-n-white air photos from 1978 and field mapping. 

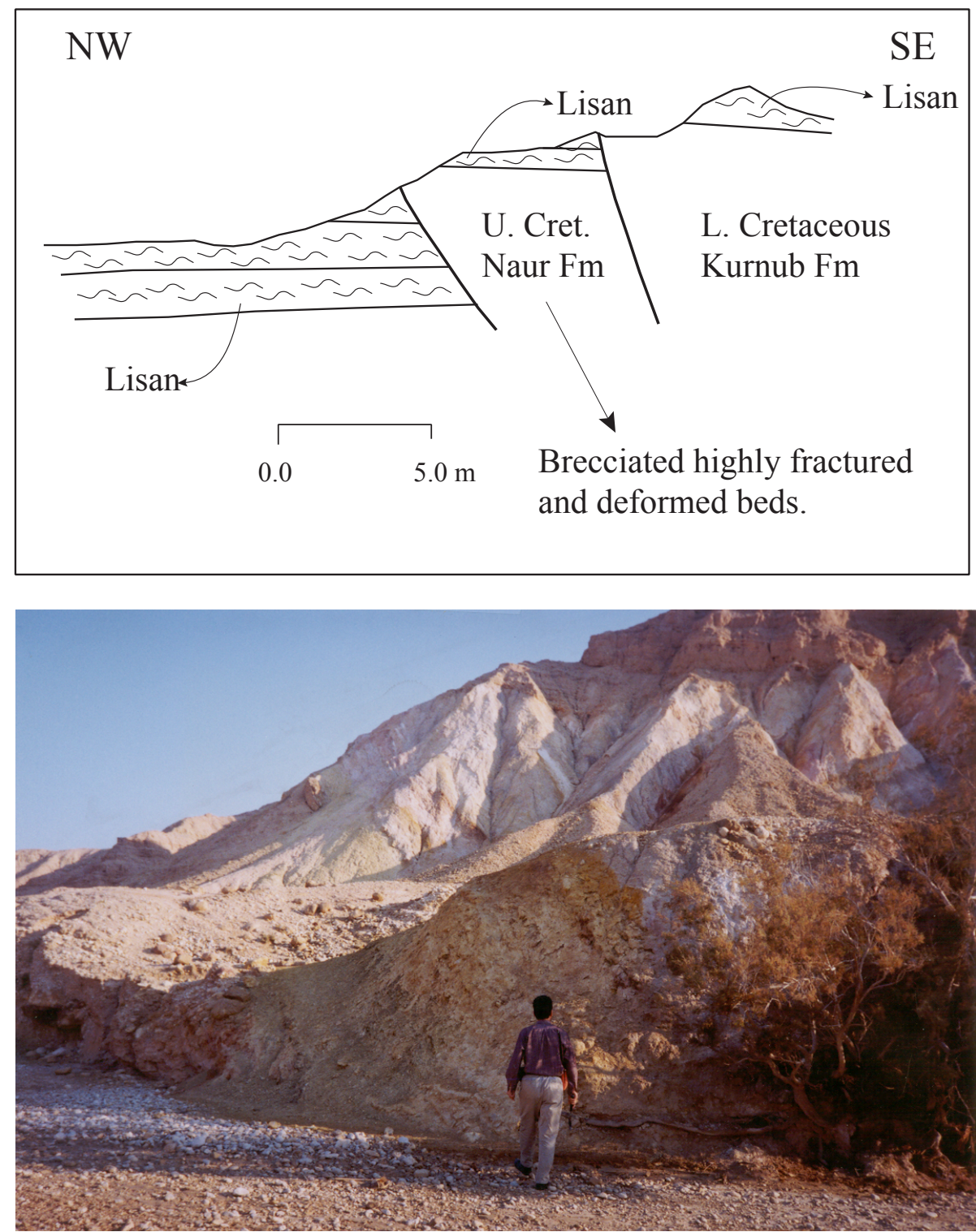

Fig. 4. (a) On the northern bank of Wadi Khunayzira, the transform is seen as a reverse fault with Lower Cretaceous (Kurnub Fm) sandstone upthrown relative to the Upper Cretaceous (Naur Fm) carbonates in the hanging wall. The Naur formation is highly fractured and the faults offset the Upper Pleistocene Lisan Formation. (b) Photograph of the structure viewed toward the north. Man standing in the foreground for scale. Location 2 on the geologic map of Fig. 3.

\section{Stratigraphy}

The stratigraphic section in the study area is composed of three dominant units:

(1) bedrock of Upper Cambrian and Cretaceous limestone, shale and sandstone,

(2) Quaternary lacustrine deposits of the Lisan Formation, and

(3) Quaternary alluvial fan deposits of Pleistocene and Holocene age (Fig. 3).

The Burj Formation is a dolomite and shale sequence of late Middle Cambrian to early Late Cambrian age. The formation outcrops in the northeastern corner of the study area in a structurally uplifted block. The Kurnub Sandstone Group is of Early Cretaceous age and outcrops along the eastern side of lower Wadi Khunayzira and in the southeastern area (Fig. 4). The Naur Limestone Formation is Cenomanian in age. Two small outcrops are found in the study area (Figs. 3, 4). In the southern area along Wadi An Nakhbar, steeply dipping limestone beds here represents the extension of deformed Dahal mountains that extend to the south. The second outcrop is located in the northeastern corner of the study area as a down-thrown fault block.

Conglomerates of probable Pleistocene age are found along the fault zone. At the Wadi An Nakhbar exposure 

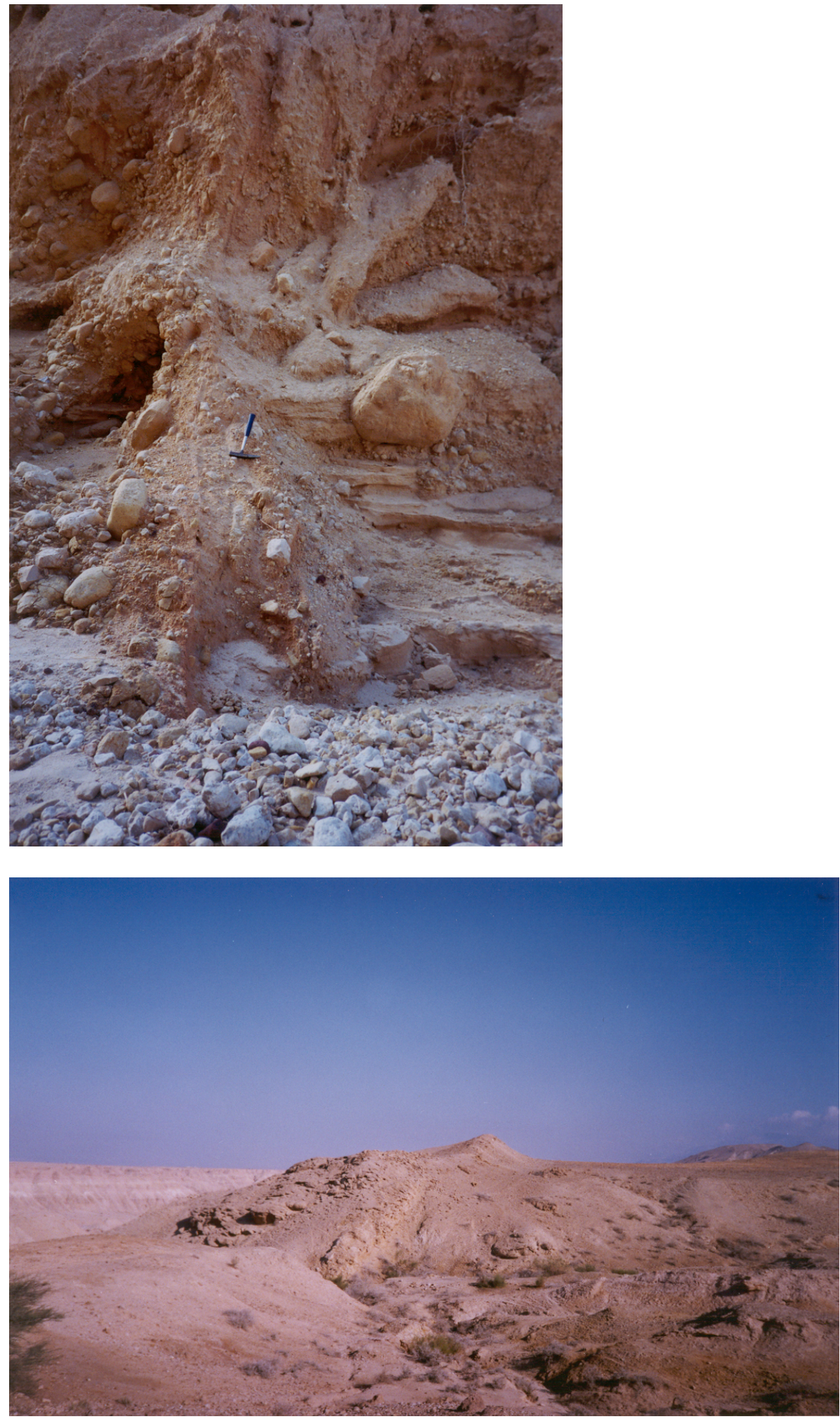

Fig. 5. DST on the northern bank of the Wadi An Nakhbar forms a $50-70 \mathrm{~cm}$ wide, zone of fault gouge that offsets the cemented pre-Lisan conglomerate. The fault extends into the wadi bed. Clasts are oriented long axis parallel to fault strike. Location 5 on the geologic map of Fig. 3.

Fig. 6. A prominent pressure ridge formed of Pre-Lisan Pleistocene conglomerate. Two former shorelines of the Lisan Lake are seen as notches in the western side of the pressure ridge. View toward the north. Location 4 on the geologic map of Fig. 3 .
(Figs. 3, 5) the angular, poorly sorted gravel and cobbles are in angular unconformable contact with the overlying, horizonally bedded Lisan Formation. These pre-Lisan gravels are highly deformed; bedding attitudes change rapidly within a short distance. They might be deposited in a narrow, pull- apart basin formed along the WAF and were deformed later by the movement along the WAF. At another location the Pre-Lisan conglomerates form a prominent pressure ridge (Figs. 6, 7). These deposits have been beveled by lake terraces with two former shorelines evident on the western side 


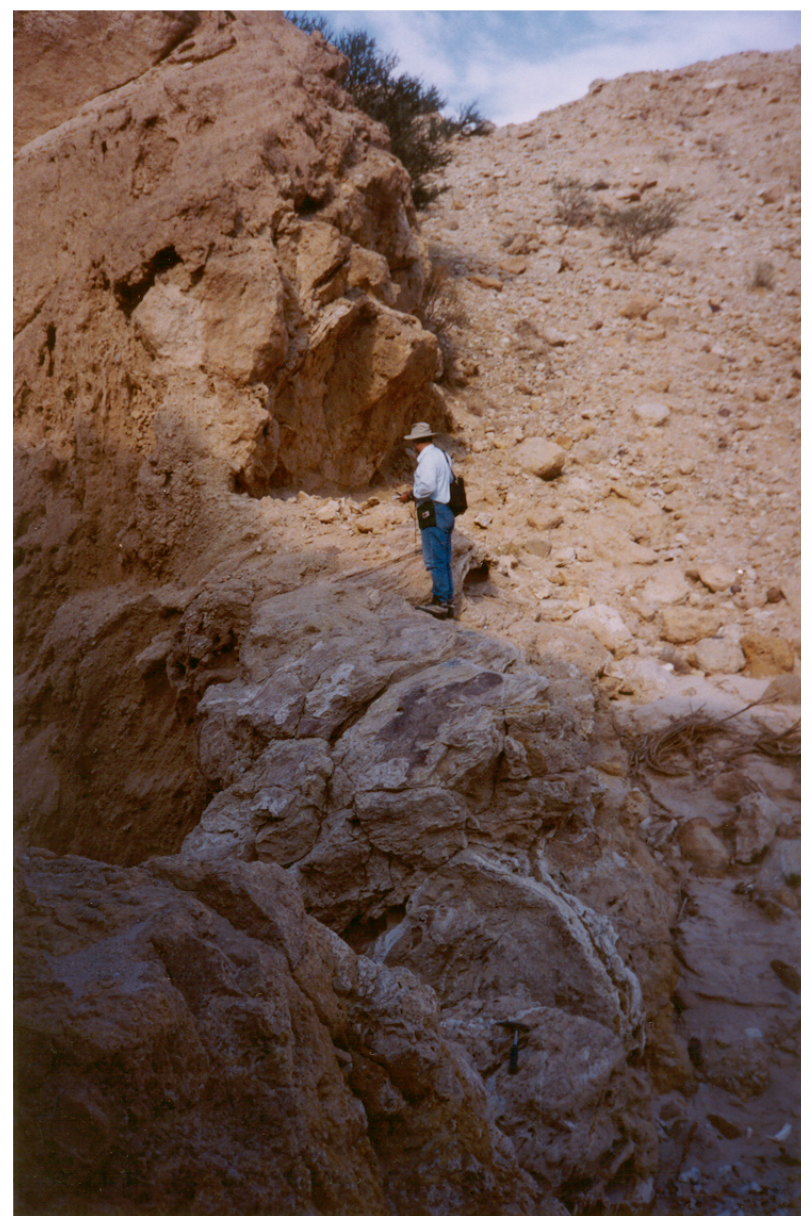

Fig. 7. The conglomerates (possibly of middle to early late Pleistocene age?) of this pressure ridge are well rounded, well sorted gravel that is strongly cemented and highly fractured. The fractures are filled with calcite. View toward the northeast. Location 4 on the geologic map of Fig. 3. of the ridge. At this location, the pre-Lisan conglomerates are well rounded, well sorted, and well cemented. The unit contains numerous calcite-filled fractures.

The upper Pleistocene Lisan Formation unconformably overlies the Kurnub Sandstone and the pre-Lisan conglomerate. At least three different facies of Lisan formation are present in the outcrop: a deep-water facies composed of thinly laminated marl and gypsum, a beach facies composed of calcarenite and oolitic sandstone with interbeds of wellrounded pebbles and cobbles, and a fan-delta facies composed of graded beds of coarse sand and gravel.

Post-Lisan conglomerate is exposed in a small outcrop at the intersection of the Wadi Khunayzira and the Wadi An Nakhbar. Other recent sediments are differentiated into alluvium and aeolian sands. These deposits are concentrated at the mouth and in the channel and tributaries of Wadi Khunayzira. Alluvial fan deposits of sand and gravel at the base of the Khunayzira escarpment are capped by a thin soil. Aeolian coarse- to medium-grained sand derived from the local bedrock blankets the eastern side of the ghor.

\section{Structures}

\subsection{Wadi Araba fault (WAF)}

In the southern end of the study area, the WAF has clear geomorphic expression with offset stream channels and alluvial fan surfaces, shutter ridges, and sag depressions. In the deep canyons of Wadi Khunayzira and Wadi An Nakhbar, the WAF plane is well exposed, cutting the Lisan and post-Lisan conglomerates. Striations were well developed on the polished pebbles (Fig. 8). The fault plane in the exposure of the Wadi An Nakhbar wall (Fig. 3, Location 5) has an attitude of $\mathrm{N} 15^{\circ} \mathrm{E}, 80 \mathrm{E}$. Striations plunge $15^{\circ}$ to the $\mathrm{N} 15^{\circ} \mathrm{E}$. The eastern block was down faulted. Within the fault zone, a Riedel shear strikes due north and dips $60^{\circ} \mathrm{E}$.

A series of pressure ridges formed along right-stepping fault traces were mapped along an eastern strand of WAF. The largest pressure ridge is cored by pre-Lisan conglomerate and measures $300 \mathrm{~m}$ in length (Fig. 3, Location 4; Fig. 6). Other smaller, rounded, and isolated pressure ridges are located along the fault trend and disappeared gradually to the north. These ridges must have formed small islands close to the shore of the Lisan Lake. These ridges represent an old trace of the WAF, the recently active WAF is located west of the pressure ridges. 

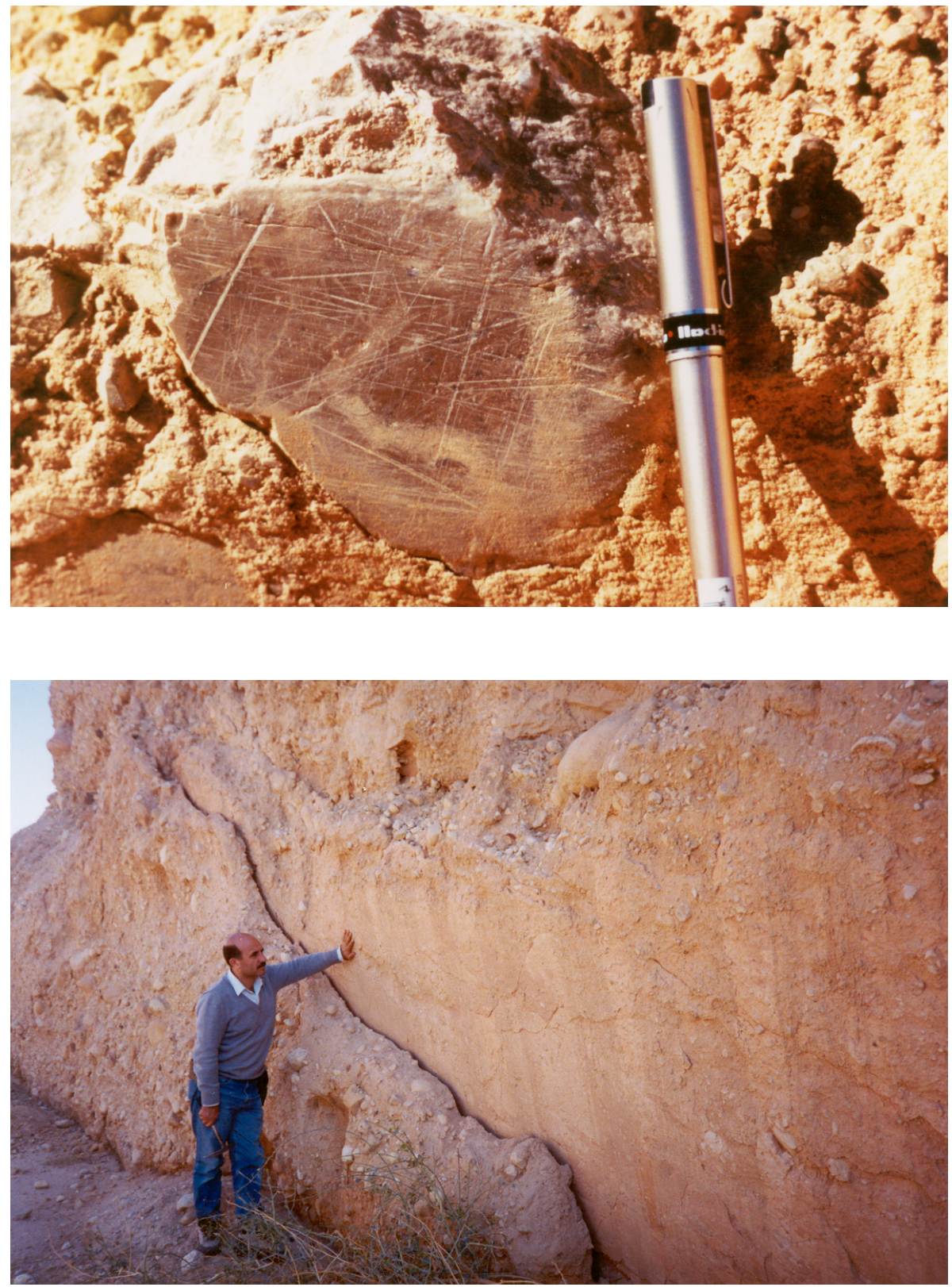

Fig. 8. Highly polished cobble along the fault plane shows several generations of slickenlines with strike-slip and dip-slip components.
Fig. 9. Exposure of the DST fault plane along Wadi An Nakhbar viewed toward the east. The fault cuts the Upper Pleistocene conglomerate. Location 3 on the geologic map of Fig. 3.
At the intersection of the Wadi An Nakhbar and the Wadi Khunayzira (Location 3 on Fig. 3), the WAF zone is well exposed. For part of its distance, the fault crosses the Wadi floor and forms a $50-70 \mathrm{~cm}$-wide dike that is filled with oriented clasts in a well-cemented conglomerate. Here the WAF has an attitude of $\mathrm{N} 15^{\circ} \mathrm{E}, 80^{\circ} \mathrm{SE}$. Several meters to the north, the WAF has the attitude of $\mathrm{N} 15^{\circ} \mathrm{E}, 75^{\circ} \mathrm{SE}$ with well-developed, striations on pebble surfaces that plunge $25^{\circ}, \mathrm{S} 20^{\circ} \mathrm{W}$ (Fig. 9). A prominent Riedel shear marked by cemented fault gouge strikes $\mathrm{N}-\mathrm{S}, 70^{\circ} \mathrm{W}$ and intersects the WAF at this location. In the southern bank of Wadi Khunyzira, the two strands of the WAF exhibit normal separation (Fig. 10). The attitude of the fault plane is $\mathrm{N} 15^{\circ} \mathrm{E}, 80^{\circ} \mathrm{NE}$ and the striations plunge $20^{\circ}$ toward the $\mathrm{S} 05^{\circ} \mathrm{W}$. The eastern block was down faulted. The vertical throw across this fault is $4 \mathrm{~m}$ as observed from the offset of a gravel bed. Using the triangle method, the horizontal displacement is calculated to be $8 \mathrm{~m}$.

The straight western bank of the Wadi Khunayzira between Location 2 and 3 on Fig. 3 is formed by the $N 5^{\circ} \mathrm{W}$, $80^{\circ} \mathrm{NE}$-trending exposed plane of a Riedel shear. Slickensides are poorly developed and striations are difficult to measure. At the same place a conjugate Riedel shear strikes $\mathrm{N} 50^{\circ} \mathrm{E}, 55^{\circ} \mathrm{NW}$.

At Location 2 (Fig. 3), the WAF shows reverse separation; the Lower Cretaceous Kurnub FM sandstone is upthrown relative to the Upper Cretaceous Naur Fm carbonates (Fig. 4). Lower and Upper Cretaceous rocks are highly fractured and brecciated. The neighboring and the overlying Lisan beds are in apparent buttress unconformable contact with the deformed bedrock. Farther to the north, where the WAF is ex- 
W

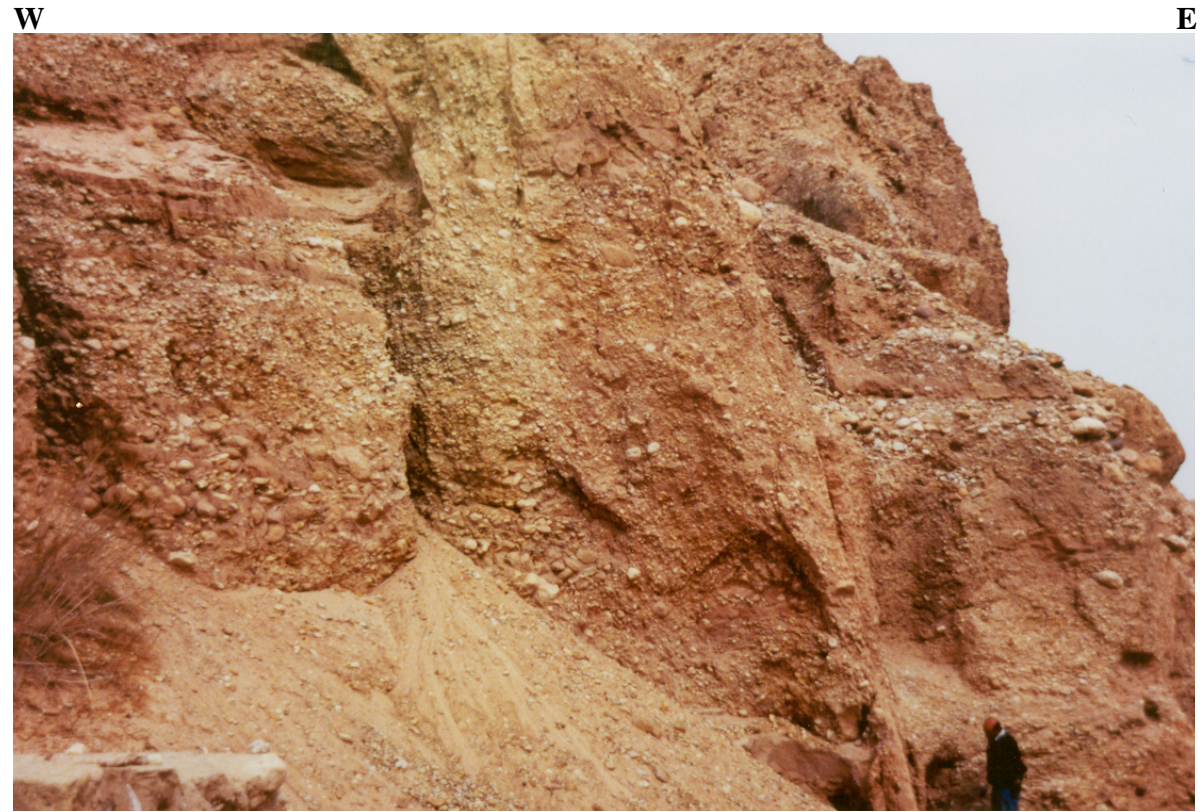

$\mathbf{E}$

Fig. 10. The DST forms a $2.5 \mathrm{~m}$ wide zone that strikes $\mathrm{N} 15^{\circ} \mathrm{E}, 80^{\circ} \mathrm{NE}$. Slickensides observed on the polished clasts of the fault plane plunge $20^{\circ}$ to the $\mathrm{S} 5^{\circ} \mathrm{W}$. The vertical, normal throw of this fault is $4 \mathrm{~m}$. Location 3 on the geologic map of Fig. 3.

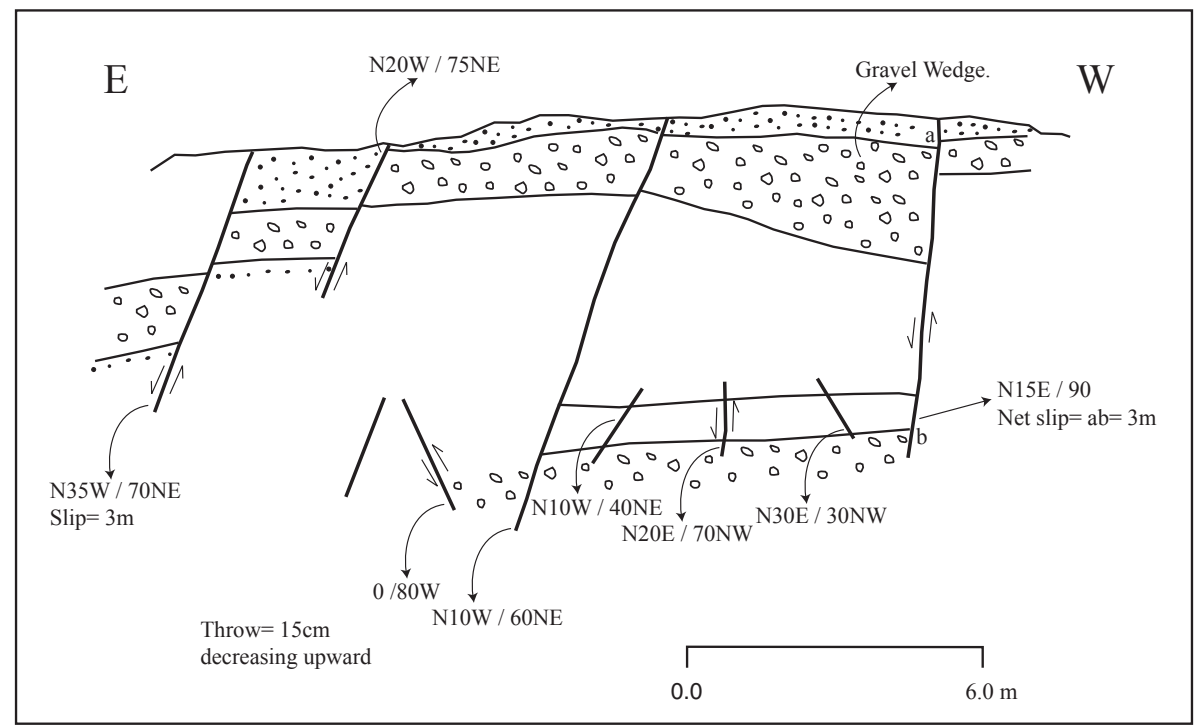

Fig. 11. Sketch map of deformation within the Lisan formation exposed along the eastern trace of the DST just south of the pressure ridge. Location 6 on geologic map. The Lisan formation at this outcrop is predominately nearshore and deltaic facies with distinct horizons of well-rounded gravel and cobbles. posed as a wall that strikes $\mathrm{N} 20^{\circ} \mathrm{E}, 85^{\circ} \mathrm{NW}$ with slip directed $25^{\circ}, \mathrm{S} 30^{\circ} \mathrm{W}$. At the same outcrop Riedel shears $\left(\mathrm{N} 05^{\circ} \mathrm{E}\right.$, $80^{\circ} \mathrm{NW}$ ) and conjugate Riedel shears $\left(\mathrm{N} 60^{\circ} \mathrm{W}, 25^{\circ} \mathrm{SW}\right)$ were measured.

North of the Khunayzira fault, the topography is gentler and there are no deep valleys to expose clear fault planes. The WAF trace can be delineated in the field and on the aerial photographs as a linear depression and as an abrupt change in the topographic elevation across the fault trace. At the northern end of the study area, where Holocene alluvial and dune sand cover the bedrock, it is difficult to delineate the fault trace, but Galli (1999) traced the WAF north of the study area.

\subsection{Khunayzira Fault}

The Khunayzira fault makes a prominent, curvilinear, $50 \mathrm{~m}$ high scarp that trends SE-NW. The base of the scarp is straighter at the northwestern end indicating higher rate of subsidence (Garfunkel et al, 1981). In the study area, the scarp is highly eroded and sinuous. The single fault scarp in the west branches in the study area to form four fault traces. The most active fault trace is the northern one that can be traced onto the recent fan of Wadi Khunayzira as a low scarp and line of vegetation. It is difficult to determine if this fault branch abuts the WAF, because it is covered by Holocene alluvial and dune sand or it may die out toward the southeast and does not cut the WAF (Location 1, Fig. 3). Detailed measurement of fractures along the Khunyzira scarp does not 
Table 1. Orientation data used in paleostress calculation

\begin{tabular}{|c|c|c|}
\hline \multicolumn{3}{|c|}{$\begin{array}{l}\text { T1: Attitudes of fault planes and their } \\
\text { slickensides of the sinistral Wadi Araba fault }\end{array}$} \\
\hline \multicolumn{2}{|l|}{ Fault plane } & Slickensides \\
\hline \multicolumn{2}{|l|}{ N15E, 80SE } & $15, \mathrm{~N} 15 \mathrm{E}$ \\
\hline \multicolumn{2}{|l|}{ N10E, 80SE } & $10, \mathrm{~S} 10 \mathrm{~W}$ \\
\hline \multicolumn{2}{|l|}{ N15E, 75SE } & $25, \mathrm{~S} 20 \mathrm{~W}$ \\
\hline \multicolumn{2}{|l|}{ N15E， 80NE } & 20, S05W \\
\hline \multicolumn{2}{|l|}{ N20E， 85NW } & $25, \mathrm{~S} 30 \mathrm{~W}$ \\
\hline \multicolumn{3}{|c|}{$\begin{array}{l}\text { T2: Attitudes of fault planes in the } \\
\text { Upper Cretaceous rocks }\end{array}$} \\
\hline \multicolumn{2}{|l|}{ Fault plane } & Slickensides \\
\hline N85E, 90 & (D) & $15, \mathrm{~N} 85 \mathrm{E}$ \\
\hline N60E，70NW & (D) & $20, \mathrm{~N} 55 \mathrm{E}$ \\
\hline N65W, 75NE & $(\mathrm{S})$ & $05, \mathrm{~S} 75 \mathrm{E}$ \\
\hline N30E, $60 \mathrm{NE}$ & $(\mathrm{S})$ & $05, \mathrm{~S} 50 \mathrm{~W}$ \\
\hline N75W, 60NE & $(\mathrm{S})$ & $00, \mathrm{~S} 70 \mathrm{E}$ \\
\hline N05E, 75SE & $(\mathrm{S})$ & $15, \mathrm{~N}-\mathrm{S}$ \\
\hline N60W, 60NE & $(\mathrm{S})$ & $15, \mathrm{~N} 60 \mathrm{~W}$ \\
\hline N70E，85NW & (D) & 20, S70W \\
\hline N50W, 65NE & $(\mathrm{S})$ & $10, \mathrm{~S} 60 \mathrm{E}$ \\
\hline N60W, 55NE & $(\mathrm{S})$ & $50, \mathrm{~N} 20 \mathrm{E}$ \\
\hline N80W, 60SW & $(\mathrm{S})$ & 30, S80W \\
\hline N90E, 90 & (D) & 30, S80W \\
\hline N90E, $70 \mathrm{~S}$ & (D) & 10, S80W \\
\hline $00 \quad 70 \mathrm{E}$ & $(\mathrm{S})$ & $20, \mathrm{~N} 10 \mathrm{E}$ \\
\hline N70E, $60 \mathrm{SE}$ & (D) & $20, \mathrm{~S} 50 \mathrm{~W}$ \\
\hline N80W, 70NE & $(\mathrm{S})$ & $15, \mathrm{~N} 90 \mathrm{E}$ \\
\hline N80W, 70NE & $(\mathrm{S})$ & $00, \mathrm{~S} 80 \mathrm{E}$ \\
\hline $75 \mathrm{~W}$ & $(\mathrm{~S})$ & $50, \mathrm{~S}$ \\
\hline $\begin{array}{l}\text { (S): Sinistral fau } \\
\text { (D): Dextral fau }\end{array}$ & & \\
\hline
\end{tabular}

show major normal faults. The dominating fractures are normal faults with only a few centimeters throw. The average strike of these fractures is $\mathrm{N} 30^{\circ} \mathrm{W}, 80^{\circ} \mathrm{NE}$. One fault with a $1 \mathrm{~m}$ offset strikes $\mathrm{N} 70^{\circ} \mathrm{W}, 60^{\circ} \mathrm{NE}$.

\subsection{Other structures}

In addition to the previously described structures, other structures are found in the study area. In Wadi An Nakhbar, $200 \mathrm{~m}$ east of the WAF, a set of faults cut the Lisan beds (Location 6, Fig. 3; Fig. 11). The fault set consists of three main faults and many subsidiary faults. The western strand is parallel to the WAF $\left(\mathrm{N} 15^{\circ} \mathrm{E}, 90\right)$ with a vertical throw of $3 \mathrm{~m}$. The middle strand shows no vertical separation and has an attitude of $\mathrm{N} 10^{\circ} \mathrm{W}, 60^{\circ} \mathrm{NE}$. The eastern strand strikes $\mathrm{N} 35^{\circ} \mathrm{W}$, $70^{\circ} \mathrm{NE}$ and has a normal separation of $3 \mathrm{~m}$. Strike-slip movement along these faults is evident by the mismatch of stratigraphic thickness of gravels across the western fault strand. No slickensides are preserved in the fine-grained and friable sediment. These faults are likely part of a negative flower structure formed along another strand of the WAF.
In Wadi Khunayzira, $50 \mathrm{~m}$ east of its intersection with Wadi An Nakhbar, a few strike-slip faults cut the post-Lisan conglomerate. The major three faults have the attitudes of $\mathrm{N} 15^{\circ} \mathrm{W}, 85^{\circ} \mathrm{NE}$ (parallel to the WAF), N05 ${ }^{\circ} \mathrm{E}, 80^{\circ} \mathrm{SE}$ and $\mathrm{N} 10^{\circ} \mathrm{W}, 70^{\circ} \mathrm{NE}$ (represent Riedel shears). And northeast of the lower course of Wadi Khunyzira, a remnant of Upper Cretaceous limestone is surrounded by Lisan sediments as a prominent pressure ridge (Fig. 3). The general trend of this ridge is $\mathrm{N} 15^{\circ} \mathrm{E}$. The rocks are highly fractured. The fault plane is marked with slickenlines. In the Cambrian sandstone, east of the mapped area, three sets of vertical fractures were measured with a major strike direction of $\mathrm{N} 90^{\circ} \mathrm{E}$ and minor joint sets that strike $\mathrm{N} 30^{\circ} \mathrm{E}$ and $\mathrm{N} 30^{\circ} \mathrm{W}$.

\section{Paleostress}

The attitude of the fault planes and striations on slickenside surfaces were measured for the WAF and the faults in the Upper Cretaceous rocks (Table 1). Upper Cretaceous rocks were chosen because they show well-developed slickensides with striations. Fault slip data for both the Lisan beds and Upper Cretaceous beds were limited due to the limited outcrop of the Upper Cretaceous rocks and due to the fact that, the WAF plane is exposed in few locations when it is intersected by the wadi courses. The fault slip data were used in kinematic and dynamic analyses (Angelier 1990; 1994) to determine the mean principal stress directions before and during the formation of the Dead Sea transform. The data were processed using the computer program "Tensor" developed by Delvaux (1993). Structural orientation data collected from the Upper Cretaceous rocks yielded a maximum compressive stress direction WNW and a maximum tension direction of NNE (Fig. 12). These trends coincide with the Syrian Arc stress field (Fig. 1; Eyal, 1996). Deformation of the Lisan formation yielded a maximum compressive stress oriented NNW and a maximum tension oriented ENE (Fig. 13). These trends coincide with formation of the WAF in the Dead Sea stress field (Eyal, 1996). Fig. (12) also shows a clear trend of the Dead Sea system superimposed on the Syrian Arc system. Separating the data of Fig. (12) gives two distinct systems, the Dead Sea system (Fig. 14) and the Syrian Arc system (Fig. 15).

\section{Discussion}

The area southeast of the Dead Sea was chosen for detailed structural analysis in order to understand the step-over from strike slip to dip slip in the Dead Sea pull-apart basin. The location of the active strand of the WAF has migrated westward during the late Quaternary. The older, pre-Lake Lisan (>63 ka) fault trace lies along a series of pressure ridges. Some of these ridges would have formed islands in the Lisan Lake and are geomorphically modified by lake terrace shorelines. Pre-Lisan conglomerate accumulated in a tectonically controlled, subsiding basin formed along an older trace of the WAF. Another old fault trace can be traced north of Wadi 

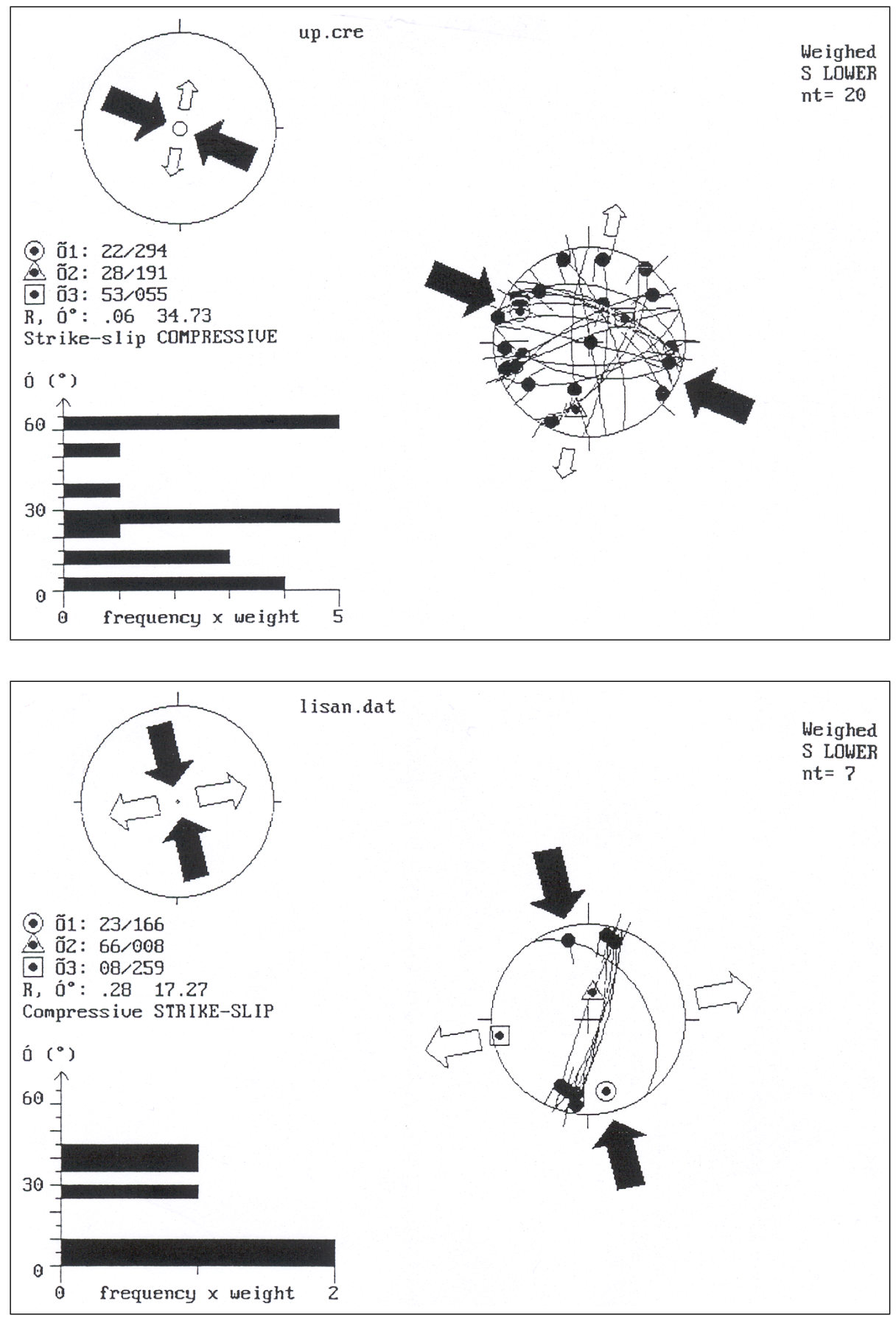

Fig. 12. Stereonet projection of fault slip orientation data from the Upper Cretaceous Naur Formation.
Fig. 13. Stereonet projection of fault slip orientation data from the Lisan Formation.
Khunayzira as an Upper Cretaceous pressure ridge. In each case, the Holocene active fault is located west of the older trace.

This study is the first to delineate the exact location of the WAF in this area. The main WAF is associated, as other strike-slip faults, with both Riedel and conjugate Riedel shears. Their orientations relative to the main fault is $10-20^{\circ}$ for the Riedel shears and $65^{\circ}-75^{\circ}$ for the conjugate Riedel, which corresponds to the Riedel model in both experiments and earthquake faults (Tchalenko and Ambraseys, 1970).

The WAF continues to the north of the study area. There is no indication that it terminates in this area and the strike- slip movement changes into dip-slip movements along the Khunayzira fault. The later fault dies out into four traces before it connects the WAF. No crosscutting relationship is observed between the two faults. These observations are not in agreement with the interpretation of Garfunkel (1981) that the Khunayzira fault represents the southern boundary of the Dead Sea pull-apart basin, where the eastern strike-slip fault terminates and the western one takes over. This result is in accordance with the postulation of ten Brink and Ben Avraham (1989) and Kashai and Croker (1987). These authors suggested that the transverse faults in the Dead Sea basin (Iddan, Amatzyahu (Khunayzira), Boqeq and Ein Gedi faults) 

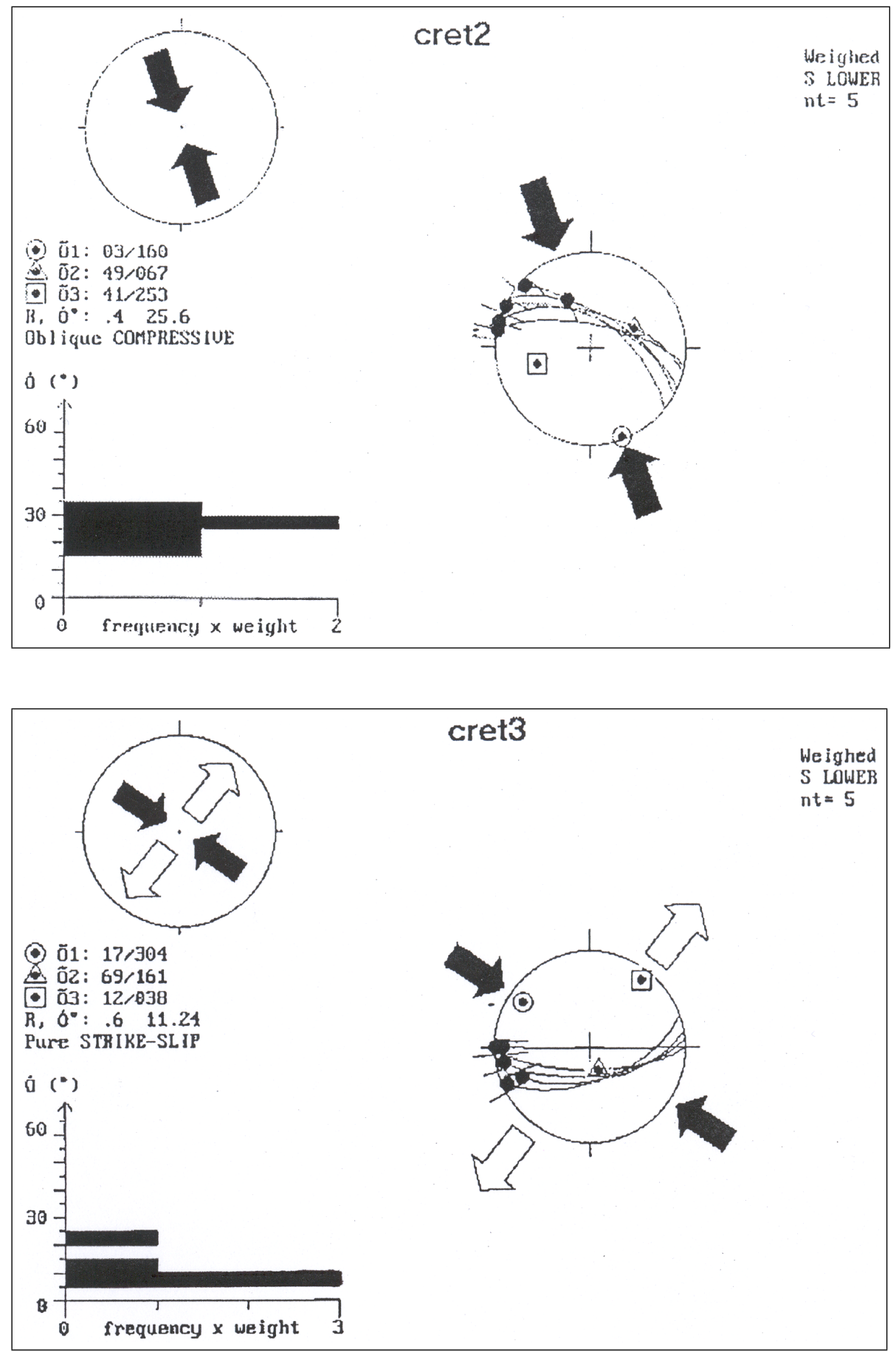

Fig. 14. Stereonet projection of fault slip orientation from the Upper Cretaceous Naur formation showing the Dead Sea paleostress system.
Fig. 15. Stereonet projection of fault slip orientation from the Upper Cretaceous Naur formation showing the Syrian Arc paleostress system. are younger than the two strands of the transform and that they were active after the formation of the basin. ten Brink and Ben Avraham (1989) suggested that the northern propagation of the southern fault (WAF) coincides with the northward migration of activity on transverse faults. This model corroborates an earlier suggestion of a northward migration of the depocenter of the Dead Sea basin proposed by Zak and Freund (1981).

Detailed study of the Bir Zreir pull-apart basin in eastern Sinai by Eyal et al. (1986) showed that both the western and eastern NNE-trending, major strike-slip faults continue beyond the oblique fault that connects them along the southern boundary of the pull-apart. Sand-silicone model experiments of oblique rifting by Tron and Brun (1991) showed that at high obliquity angles, deformation is partitioned between two distinct sets of oblique-slip and strike-slip fault trends. Sandbox analog models of pull-apart basins by McClay and Dooley (1995) and Dooley and McClay (1997) showed that the sidewall faults of the pull-apart basins show changes in kinematics from dominantly dip-slip extension in their cen- 
tral section to oblique slip and strike slip at either end where they merge with the principal deformation zone. These authors compare their analog models with natural examples of pull-apart basins, including the Dead Sea and show many strong similarities in structural geometries and stratal architectures. These models are a reasonable fit for development of active faults mapped along the southern DST, and support partitioning of strain onto transform-parallel normal faults proposed by Ben-Avraham and Zoback (1992). Transform normal extension may better explain the formation of basins along the DST than the classic pull-apart basin model.

\section{Conclusions}

Study of the neotectonic structures exposed in the Dead Sea basin can reveal much about the deformation processes that operate in the uppermost crust and the formation of transtensional basins. The stratigraphic section in the study area is composed of three dominant units:

(1) Cambrian and Cretaceous limestone, shale, and sandstone,

(2) Quaternary lacustrine deposits of the Lisan Formation, and

(3) Quaternary alluvial fan deposits of Pleistocene and Holocene age.

The oldest rocks in the study area are the Cambrian Burj formation, the Lower Cretaceous Kurnub sandstone, and the Upper Cretaceous limestones. Fracture orientation data indicate that these rocks have been folded and uplifted during an early phase of tectonic deformation when the transform plate boundary was formed in the Miocene. The Cretaceous rocks also core pressure ridges within the present stress regime. Unconformably overlying the Paleozoic and Mesozoic bedrock are tilted Pleistocene fluvial gravels. These conglomerates may correlate to the Samra Formation (350 to $116 \mathrm{ka}$; Kaufman et al., 1992). The contact of the flat-lying Late Pleistocene lacustrine deposits of the Lisan Formation with the older units forms both buttress and angular unconformities. Fault slip data indicate the maximum principal stress is oriented NNW-SSE and minimum principal stress is directed ENE-WSW for post-Lisan deformation.

Acknowledgements. This work is partially funded by the Yarmouk University, grant number 62/98. This research was also partially supported by a grant from the Petroleum Research fund of theAmerican Chemical Society to Niemi. The authors would like to thank the Jordan Valley Authority for providing accommodation during the fieldwork. We also thank Nasser Mansoor for assistance in drafting the figures. We thank two anonymous reviewers for commenting on an earlier version of this manuscript.

\section{References}

Al-Diabat, A.: Paleostress and strain analysis of the Cretaceous rocks in the eastern margin of the Dead Sea transform, Jordan, unpub. Ph. D. thesis, University of Baghdad, Baghdad, Iraq, 1999.

Angelier, J.: Inversion of field data in fault tectonics to obtain the regional stress III: A new rapid direct inversion method by analytical means, International Journal of Geophysics, 103, 363-376, 1990.

Angelier, J.: Fault slip analysis and paleostress reconstruction, in: Hancock, P. (Ed.): Continental Deformation, Pergamon Press, Oxford, 53-100, 1994.

Aydin, A. and Nur, A.: Evolution of pull-apart basins and their scale independence, Tectonics, 1, 91105, 1982.

Bartov, Y., Steinitz, G., and Eyal, Y.: Sinistral movement along the Gulf of Aqaba - its age and relation to opening of the Red Sea, Nature, 285p, 220-221, 1980.

Ben-Avraham, Z. and Zoback, M. D.: Transform-normal extension and asymmetric basins: an alternative to pull-apart models, Geology, 20, 423-426, 1992.

Bender, F.: Geological map of Jordan, 1:100 000, Geological Survey of the Federal Republic of Germany, Hannover, 1975.

Chu, D. and Gordon, R. G.: Current plate motions across the Red Sea, Geophysical Journal International, 135, 313-328, 1998.

Courtillot, V., Armijo, R., and Tapponnier, P.: Kinematics of the Sinai triple junction and a two phase model of Arabia-Africa rifting, Geological Society Special Publications, 28, 559-573, 1987.

Crowell, J. C.: Origin of Late Cenozoic basins in southern California, S.E.P.M. Special Publication, 22, 190-204, 1974.

Delvaux, D.: The TENSOR program for paleostress reconstruction: examples from the east African and the Baikal rift zones. EUG VII Strasbourg, France, 4-8 April 1993, Abstract supplement No 1 to Terra Nova, 5, 216, 1993.

Dooley, T. and McClay, K.: Analog modeling of pull-apart basins, AAPG Bulletin, 81, 1804-1826, 1997.

Eyal, M., Eyal, Y., Bartov, Y., and Steinitz, G.: The tectonic development of the western margin of Elat (Aqaba) rift, Tectonophysics, 80, 39-66, 1981.

Eyal, Y. and Reches, Z.: Tectonic analysis of the Dead Sea rift region since the Late Cretaceous based on mesostructures, Tectonics, 2, 167-185, 1983.

Eyal, Y., Eyal, M., Bartov, Y., Steinitz, G., and Folkman, Y.: The origin of the Bir Zreir rhomb-shaped graben, Eastern Sinai, Tectonics, 5, 267-277, 1986.

Eyal, Y.: Stress field fluctuations along the Dead Sea rift since the middle Miocene, Tectonics, 15, 1, 157-170, 1996.

Freund, R., Garfunkel, Z., Zak, I., Goldberg, M., Weissbrod, T., and Derin, B.: The shear along the Dead Sea rift, Royal Society of London Philosophical Transactions, v. A267, 107-130, 1970.

Galli, P.: Active tectonics along the Wadi Araba-Jordan Valley transform fault, Journal of Geophysical Research, 104, 27772796, 1999.

Gardosh, M., Kashai, E., Salhov, S., Shulman, H., and Tannenbaum, E.: Hydrocarbon exploration in the southern Dead Sea area, in: Niemi, T. M., Ben-Avraham, Z., and Gat, J. (Eds.): The Dead Sea: The Lake and Its Setting, Oxford University Press, New York, NY, 57-72, 1997.

Garfunkel, Z.: The history and formation of the Dead Sea basin, in: Niemi, T. M., Ben-Avraham, Z., and Gat, J. (Eds.): The Dead Sea: The Lake and Its Setting, Oxford University Press, New York, NY, 36-56, 1997. 
Garfunkel, Z.: Internal structure of the Dead Sea leaky transform (rift) in relation to plate kinematics, Tectonophysics, 80, 81-108, 1981.

Garfunkel, Z., Zak, I., and Freund, R.: Active faulting in the Dead Sea rift, Tectonophysics, 80, 1-26, 1981.

Ginat, H., Enzel, Y., and Avni, Y.: Translocated Plio-Pleistocene drainage systems along the Arava fault of the Dead Sea transform, Tectonophysics, 284, 151-160, 1998.

Kashai, E. L. and Croker, P. F.: Structural geometry and evolution of the Dead Sea Jordan rift system as deduced from new subsurface data, Tectonophysics, 141, 33-60, 1987.

Katzman, R., ten Brink, U. S., and Lin, J.: Three-dimensional modeling of pull-apart basins: Implications for the tectonics of the Dead Sea basin, Journal of Geophysical Research, 100, 62956312, 1994.

Kaufman, A., Yechieli, Y., and Gardosh, M.: Reevaluation of the lake-sediment chronology in the Dead Sea basin, Israel, based on new ${ }^{230} \mathrm{Th} / \mathrm{U}$ dates, Quaternary Research, 38, 292-304, 1992.

Klinger Y., Avouac, J. P., Abou Karaki, N., Dorbath, L., Bourles, D., and Reyss, J. L.: Slip rate on the Dead Sea transform in northern Araba valley (Jordan), Geophys. J. Int., 142, 755-768, 2000.

McClay, K. and Dooley, T.: Analogue models of pull-apart basins, Geology, 23, 711-714, 1995.

Niemi, T. M., Zhang, H., Atallah, M., and Harrison, J. B. J.: Late Pleistocene and Holocene slip rate of the Northern Wadi Araba fault, Dead Sea Transform, Jordan, Journal of Seismology, 5, 449-474, 2001

Quennell, A. M.: Tectonics of the Dead Sea rift, International Geological Congress 20th, Association of African Geological Surveys, 385-405, 1959.

Tarawneh, B.: The geology of the Fifi area, Map Sheet No. 3051 I: National Resources Authority, Geology Directorate, Amman,
Jordan, 46p, Map scale 1:50 000, 1992.

Tchalenko, J. S. and Ambraseys, N. N.: Structural analysis of the Dasht-e Bayaz (Iran) earthquake fractures, Geological Society of America Bulletin, 81, 41-60, 1970.

ten Brink, U. S., Rybakow, M., and Al-Zoubi, A.: Anatomy of the Dead Sea transform: Does it reflect continuous changes in plate motion? Geology, 27, 10, 887-890, 1999.

ten-Brink, U. S., Katzman, R., and Lin, J.: Three-dimensional models of deformation near strike-slip faults, Journal of Geophysical Research, 101, 16205-16220, 1996.

ten-Brink, U. S., Ben-Avraham, Z., and Bell, R. E.: Structure of the Dead Sea pull-apart basin from gravity analysis, Journal of Geophysical Research, 98, 21 887-21 894, 1993.

ten Brink, U. S. and Ben-Avraham, Z.: The anatomy of a pull-apart basin: Seismic reflection observations of the Dead Sea basin, Tectonics, 8, 333-350, 1989.

Tron, V. and Brun, J.-P.: Experiments on oblique rifting in brittleductile systems, Tectonophysics, 188, 71-84, 1991.

van Eck, T. and Hofstetter, R.: Fault geometry and spatial clustering of microearthquakes along the Dead Sea-Jordan rift fault zone, Tectonophysics, 180, 15-27, 1990.

Wilcox, R. E., Harding, T. P., and Seely, D. R.: Basic Wrench Tectonics, American Association of Petroleum Geologists Bulletin, 57, 1, 74-96, 1973.

Zak, I. and Freund, R.: Recent strike-slip movements along the Dead Sea rift, Israel Journal of Earth Sciences, 15, 33-37, 1966.

Zak, I. and Freund, R.: Assymmetry and basin migration in the Dead Sea rift, Tectonophysics, 80, 27-38, 1981.

Zhang, H.: Late Pleistocene and Holocene slip rate of the Northern Wadi Araba fault, Dead Sea Transform, Jordan, M. S. Thesis, Geosciences Dept., UMKC, 128p, 1998. 